\section{Biologia Molecular das Neoplasias de Próstata}

\section{RESUMO}

O câncer de próstata (CP) é uma das principais causas de doença e morte, representando no Brasil a segunda causa de óbitos por câncer em homens. A hiperplasia prostática benigna (HPB) é uma doença progressiva de alta prevalência, com evidências histológicas em $50 \%$ dos homens aos 50 anos e $90 \%$ aos 80 anos de idade. A patogênese das neoplasias prostáticas tem sido associada à ação dos androgênios e a seu receptor nuclear específico, embora os mecanismos moleculares que envolvem os processos de proliferação, diferenciação e apoptose não estejam bem estabelecidos, assim como os mecanismos de transformação neoplásica e carcinogênese. Co-ativadores e co-repressores podem também contribuir para a carcinogênese prostática, ligando-se diretamente aos receptores nucleares, recrutando proteínas adicionais e interagindo com a maquinaria transcricional para aumentar a transcrição de genes-alvo. Polimorfismos do receptor de androgênios e da $5 \pi$ redutase tipo 2 foram identificados e poderiam estar associados com risco para CP. Genes reguladores do ciclo celular e da apoptose, bem como fatores de crescimento, também participam de processos relacionados com a tumorigênese prostática. Assim, alterações no padrão da expressão gênica do tecido normal podem levar ao desenvolvimento do fenótipo maligno e potencialmente estes genes podem servir como marcadores de prognóstico. Com o advento de novas tecnologias moleculares, o número de genes marcadores potenciais para $\mathrm{O} \mathrm{CP}$ cresce dia a dia, mas os dados atuais requerem ainda validação com maior número de amostras e correlação com o processo da doença. Trazê-los do ambiente de laboratório para o uso clínico requer uma análise rigorosa e há, portanto, um longo caminho ainda a percorrer. (Arq Bras Endocrinol Metab 2005;49/5:797-804)

Descritores: Próstata; Câncer; Hiperplasia; Androgênios; Genes; Receptor de androgênios

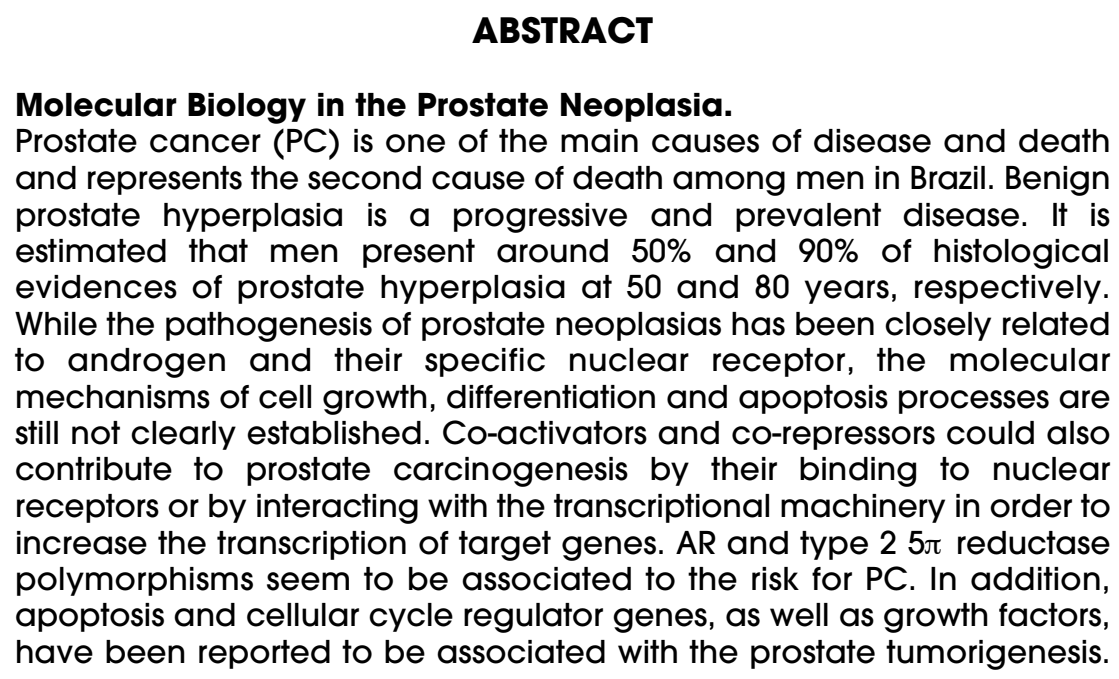

Arq Bras Endocrinol Metab vol $49 n^{\circ} 5$ Outubro 2005

\section{atualização}

\author{
Ilma Simoni Brum \\ Poli Mara Spritzer \\ Maria Mitzi Brentani
}

Laboratório de Endocrinologia Molecular e Neuroendocrinologia, Departamento de Fisiologia,

Universidade Federal do Rio

Grande do Sul (ISB \& PMS);

Unidade de Endocrinologia

Ginecológica, Hospital de Clinicas de Porto Alegre (PMS); e

Disciplina de Oncologia (LIM24),

Departamento de Radiologia,

Faculdade de Medicina,

Universidade de São Paulo (MMB).
Recebido em 08/08/05

Revisado em 15/08/05 Aceito em 20/08/05 
Therefore, changes on the gene expression of normal tissue may be associated to the development of malign phenotype and these genes could be regarded as candidates of prognosis markers. The number of these genes increases every day but the present data needs further studies and correlation with the disease progression. (Arq Bras Endocrinol Metab 2005;49/5:797-804)

Keywords: Prostate; Cancer; Hyperplasia; Androgens; Genes; Androgen receptor

O CÂNCER DE PRÓstaTa é uma das principais causas de doença e morte nos Estados Unidos e Europa Ocidental. O risco de desenvolver a doença é de $\mathrm{l} \mathrm{em}$ cada 6 homens e o risco de óbito por câncer metastático é de 1 para cada 30 homens (1). No Brasil, o câncer de próstata representa, atualmente, a segunda causa de óbitos por câncer em homens, sendo superado apenas pelo de pulmão. Para 2005, há uma estimativa de ocorrência de 46.330 casos novos para este tipo de câncer, correspondendo a um risco estimado de 51 casos novos a cada 100.000 homens. Considerando as diferentes regiões do país, o câncer de próstata apresenta risco estimado de 69/100.000 na região Sul, 63/100.000 na região Sudeste, 46/ 100.000 na região Centro-Oeste, $34 / 100.000$ na região Nordeste e 20/100.000 na região Norte (2).

A incidência do câncer de próstata $(\mathrm{CaP})$ varia entre os diferentes grupos étnicos. Nos Estados Unidos, a incidência é maior entre os afro-americanos $(250 / 100.000)$, porém a população de origem caucasiana também tem taxas altas de incidência. $\mathrm{Na}$ Europa, a Escandinávia possui índices de mortalidade maiores em relação aos países localizados ao Sul do continente. Nações asiáticas têm os menores índices de incidência e mortalidade por câncer de próstata no mundo (1).

A hiperplasia prostática benigna (HPB) é a doença mais prevalente da próstata, com aproximadamente $50 \%$ dos homens apresentando evidências histológicas de HPB aos 50 anos e $90 \%$ aos 80 anos de idade. A HPB é considerada uma doença progressiva, definida como o crescimento contínuo da próstata, levando à intensificação de sintomas e ao aumento do risco de complicações ao longo do tempo, como a retenção urinária aguda e cirurgia devido à HPB (3).

A ação dos androgênios tem sido amplamente demonstrada na próstata humana, seja por sua ação na morfogênese, diferenciação, proliferação celular e secreções da glândula prostática, quanto na resposta ao tratamento hormonal do CaP e HPB $(1,3,4)$. Da mesma forma, a patogênese das neoplasias prostáticas tem sido estreitamente associada à ação destes hormônios $(5,6)$. Contudo, os mecanismos moleculares que envolvem os processos de proliferação, diferenciação e apoptose não estão ainda bem estabelecidos, assim como os mecanismos de transformação neoplásica e carcinogênese.

Os androgênios exercem sua ação através de receptores nucleares, que são fatores de transcrição e regulam a expressão de genes-alvo por mecanismo dependente do ligante. A expressão gênica do receptor de androgênios (AR) pode ser modulada em múltiplos níveis por mecanismos de transcrição, pós-transcrição e pós-tradução (7). Complexos formados por co-ativadores ou co-repressores promovem uma modificação local da estrutura da cromatina e também participam do controle da expressão gênica (8). A regulação desses processos requer a ativação de genes responsivos e dependentes da ativação do complexo androgênioreceptor.

\section{O RECEPTOR DE ANDROGÊNIOS E CO-REGULADORES}

O desenvolvimento normal, o trofismo e a funcionalidade da próstata são dependentes de androgênios, que atuam através do seu receptor específico, o AR. Da mesma forma, o desenvolvimento e progressão da HPB e do CaP estão associados aos androgênios e ao AR $(9,10)$. Além disso, mutações no AR podem ocorrer com certa freqüência, especialmente em tumores avançados de próstata, que se tornam resistentes à terapia hormonal (11).

Co-reguladores (co-ativadores ou co-repressores), associados com a especificidade do ligante ao AR ou com sua atividade transcricional, podem também contribuir para a carcinogênese prostática. Estas proteínas podem atuar como moléculas adaptadoras, ligando-se diretamente aos receptores nucleares, recrutando proteínas adicionais e interagindo com a maquinaria transcricional basal para aumentar a transcrição de genes-alvo (12-14).

Evidências sugerem que a expressão dos genes de vários co-ativadores podem estar aumentadas no CaP como a família dos SRC (steroid receptor coactiva tors), relacionados com o AR. Os SRC abrangem o SRC-1, o TIF-2 (transcriptional intermediary factor) e o SRC-3 (9). Além destes, os co-ativadores ARA ( $A R$ associated protein), que compreendem ARA70, ARA55, ARA54, ARAl60, também parecem estar envolvidos na formação de tumores prostáticos 
$(15,16)$. Co-repressores que funcionam como reguladores negativos para reprimir ou silenciar a atividade transcricional basal, também têm sido associados com a tumorigênese prostática. Os mais citados são ciclina Dl (17), p53 (18) e Pyk2 (19).

Recentemente foi descrito outro co-ativador do receptor de androgênios, o FHL2 (four and a half LIM domains) (20). A expressão de FHL2 parece ser específica da próstata e do miocárdio. A proteína SHP (Short Heterodimer Partner), por outro lado, é um co-inibidor que interage com vários receptores nucleares $(\mathrm{AR}, \mathrm{ER}$ e RXR), inibindo a atividade transcricional (21).

\section{POLIMORFISMOS DO AR E DA $5 \pi$ REDUTASE TIPO 2}

O gene do $A R$ está localizado no cromossomo Xql112. Este gene codifica o receptor de androgênios, que modula a resposta androgênica e estimula a expressão de genes associados com o fenótipo diferenciado da próstata, como o antígeno prostático específico, o PSA (22). O exon 1 , que codifica o domínio de transativação, contém um microssatélite CAG altamente polimórfico, um polimorfismo de nucleotíodeo simples no codon 211 (G1733A) e uma repetição menos polimórfica, a repetição GGN $(23,24)$.

Em experimentos de transfecção, o comprimento da repetição CAG é inversa e linearmente correlacionado com a atividade de transativação transcricional do AR (22). Assim, um número menor de repetições estaria relacionado a um alto risco de desenvolvimento do câncer de próstata ou sua progressão $(25,26)$. Não está ainda definida se a extensão do segundo microssatélite do gene do AR, consistindo das repetições GGN e que codifica um trato poliglicínico, promove algum efeito sobre o fenótipo dos indivíduos afetados. O polimorfismo StuI permite a identificação de dois alelos (S1/S2), para os quais uma associação com o risco aumentado de câncer de próstata tem sido investigado (27).

A clonagem e caracterização do gene da $5 \pi$ redutase tipo 2 (SRD5A2), mapeado no cromossomo $2 \mathrm{p} 23$, foram seguidas pela descrição de vários polimorfismos neste gene (28). Um polimorfismo leucina/ valina no códon 89 (Val89Leu) foi identificado, com $\mathrm{o}$ alelo Leu estando associado com menor atividade da $5 \pi$ redutase. Foi sugerido que este polimorfismo esteja associado a menor risco de $\mathrm{CaP}$ em decorrência de menores concentrações intra-prostáticas de DHT (29). Ao contrário, uma outra variante com substituição de alanina por treonina no aminoácido 49 (Ala49Thr) foi correlacionada com aumento na atividade da $5 \pi$ redutase, e associada com maior risco para $\mathrm{CaP}(30)$.

\section{FATORES DE CRESCIMENTO E OUTROS GENES-ALVO DOS ANDROGÊNIOS}

A progressão no ciclo celular é regulada por múltiplos fatores, entre eles hormônios e fatores de crescimento. Diversos estudos têm mostrado que fatores que interferem nas vias de sinalização intracelulares determinam o crescimento celular ou sua inibição, através da regulação do ciclo celular. Por outro lado, células neoplásicas freqüentemente apresentam anormalidades na resposta celular a fatores de crescimento e seus receptores, proteínas envolvidas nas vias de transdução do sinal hormonal e fatores de transcrição nucleares. Estas alterações refletem uma desregulação de vias de sinalização oncogênicas que promovem proliferação, inibem apoptose e habilitam células cancerosas a disseminar-se e estimular a angiogênese (31).

Entre os fatores de crescimento envolvidos com as neoplasias de próstata, pode-se citar a expressão aumentada dos genes Her2, da família do EGF (13), bem como a do Akt (32), em CaP refratários ao tratamento hormonal. $\mathrm{O}$ fator de crescimento transformante beta (TGF $\pi$ ), por sua vez, parece atuar como um inibidor do crescimento do epitélio prostático e também como um fator de diferenciação do estroma prostático (33). Os mediadores da sinalização do TGFл são as proteínas Smad, que funcionam como fatores de transcrição regulados por fosforilação. Em células de $\mathrm{CaP}$, a menor sensibilidade ao TGF $\pi$ ocorre pela redução dos receptores de TGF゙ e conseqüente diminuição da fosforilação de Smad3. Menores níveis de Smad3 fosforilada removem um mecanismo inibitório para a transcrição do $\mathrm{AR}$, liberando a proliferação e expressão do PSA mesmo em presença de baixos níveis de androgênios após a terapia de retirada de androgênios (34).

Genes reguladores do ciclo celular, como os proto-oncogenes myc, fos e jun, e genes reguladores da apoptose como bcl-2, p53 e p21, também participam dos processos de proliferação e formação tumoral de diversos tecidos incluindo a próstata (3538). Outros genes envolvidos com a ação androgênica podem também ser listados: ras, $R b$, Wafl, transdutores de sinal intracelular como a proteína quinase $\mathrm{C} \mathrm{e}$ GTPase, entre outros (39).

$\mathrm{Bcl} 2$ é um gene antiapoptótico que está envolvido em múltiplos passos da carcinogênese da próstata, podendo participar na supressão da apoptose e/ou na 
estimulação da angiogênese tumoral (40). Estudos em $\mathrm{CaP}$ demonstraram que a expressão do bcl-2 está associada ao receptor de androgênios (41).

O gene do p53, também conhecido como TP53 (Tumor Protein 53), codifica uma proteína supressora de tumor. A proteína p53 está relacionada com os mecanismos de reparação do DNA, parada em Gl e indução de apoptose, e alterações na expressão desta proteína foram observadas em células derivadas de neoplasia prostática intraepitelial e na HPB $(18,42)$.

O gene $p 21$, um inibidor de quinases dependente de ciclinas, também conhecido como WAFl ou CIPl, codifica uma proteína que provoca a parada do ciclo celular na fase Gl. Sua expressão é ativada tanto por sinais fisiológicos quanto em presença de dano na fita de DNA. A expressão do $p 21$ pode ser modulada pelo AR e pelo $b c l-2$, fato este relevante na progressão tumoral (43).

Como exposto, uma série de modificações em genes importantes que resultam em uma alteração significativa no padrão da expressão gênica do tecido normal pode levar ao desenvolvimento do fenótipo maligno, e potencialmente estes genes podem servir como marcadores de prognóstico. Perfis de expressão gênica global podem ser de grande ajuda na compreensão do mecanismo molecular responsável pelo desenvolvimento de câncer da próstata.

De uma maneira geral, espera-se que a exploração de marcadores moleculares prognósticos atinja os seguintes objetivos: 1) elucidação dos determinantes moleculares da progressão do câncer de próstata; 2 ) estratificação dos estágios da doença; 3 ) predição da resposta à prostatectomia, radiação ou terapia neoadjuvanate; 4) aquisição da insensibilidade a androgênios.

\section{ANÁLISE DA EXPRESSÃO GÊNICA: ASPECTOS TÉCNICOS}

Duas metodologias são mais utilizadas: a hibridização com arrays de alta densidade e análise seriada da expressão gênica (SAGE), as quais estão tendo um grande impacto na possibilidade de ter uma visão global dos processos celulares.

Há duas variedades básicas de microarrays. $\mathrm{Na}$ primeira, em lâminas de vidro, são fixados fragmentos de DNA correspondentes aos genes de interesse e que servem como alvos para a hibridização com DNA complementar derivado do mRNA extraído do tecido ou cultura celular que está sendo analisado.

A hibridização é medida por fluorescência obtida por anterior marcação do DNA com marcadores fluo- rescentes. A intensidade da fluorescência é quantificada e é proporcional à quantidade do $\mathrm{cDNA}$ depositado.

Oligonucleotídeos são seqüências curtas usualmente de $50-80$ pares de bases, os quais são depositados em lâminas de vidro. A principal vantagem desta metodologia é que o controle de qualidade da seqüência imobilizada é realizado durante a síntese, ao passo que o seqüenciamento precisa ser realizado quando se usam fragmentos de cDNA. De outro lado, comprimentos maiores das sondas de DNA fornecem sinais mais fortes e são mais estáveis (44).

A técnica Análise Serial da Expressão Gênica (SAGE - Serial analysis of gene expression) é baseada em 3 princípios: primeiro, uma pequena seqüência de cDNA de 9-14 pares de bases (tag ou etiqueta) isolada de uma posição definida dentro de cada transcrito contém informações suficientes para identificar um único transcrito; segundo, múltiplos tags podem ser concatenados e seqüenciados, revelando a seqüência de milhares de tags simultaneamente; terceiro, este resultado é uma estimativa quantitativa e qualitativa da expressão gênica dada pela determinação da abundância de tags individuais e a identificação do gene correspondente a cada respectivo tag $(45,46)$.

Resumidamente, o cDNA de fita dupla é sintetizado a partir do RNA total usando um iniciador oligo(dT) unido a partículas magnéticas. O cDNA é então digerido com uma enzima de restrição, que reconhece a seqüência CATG e, conseqüentemente, corta o cDNA na porção mais próxima à ponta 3 ', que é importante para a identificação definitiva do gene correspondente. Os adaptadores que são unidos ao cDNA contêm um sítio de reconhecimento para uma segunda enzima de restrição que cliva o cDNA a uma distância 3' definida do sítio de reconhecimento, liberando um fragmento pequeno de cDNA, o tag (etiqueta). Estes fragmentos são combinados e ligados, formando a construção adaptador-ditag-adaptador. Estes produtos são amplificados por PCR com iniciadores específicos para cada adaptador, depois são isolados e clivados para a liberação do adaptador. Os ditags criados são então ligados entre si, formando os concatâmeros, que são clonados e seqüenciados. Devido à presença da seqüência CATG nos concatâmeros, que delimita o início e o fim de cada tag, o programa SAGE pode isolar os tags dos concatâmeros. Finalmente, o programa calcula a ocorrência de cada tag e identifica o transcrito, por comparação com os bancos de dados do GenBank ou UniGene. Além disso, a quantidade de vezes em que o tag for observado fornece uma informação direta, estimando a expressão do transcrito correspondente. 
O desenvolvimento destas tecnologias permite determinar o nível de expressão de milhares de genes em uma única amostra. Um dos aspectos fundamentais desta pesquisa é que em muitos casos a análise de muitos genes leva à descoberta de um conjunto menor de genes que fornecerá uma informação essencial sobre o sistema biológico que está sendo estudado, podendo ser utilizado posteriormente em estudos em larga escala.

\section{Perfis gênicos em câncer de próstata}

Vários grupos comparam diferenças de expressão entre tecido normal de próstata e câncer de próstata.

Um array comercial de 588 genes foi utilizado por Elek e cols. (47), comparando 3 amostras de carcinoma com 1 amostra normal, e 19 genes diferencialmente expressos foram detectados. Ernst e cols. (48) verificam também a existência de genes discriminando carcinoma de próstata e tecido normal usando um array de 12.6000 seqüências. Além da hepsina, que é também uma serina protease associada à membrana, outros genes estavam alterados, tais como LDL-fosfolipase A2 e um gene antiapoptótico (PYCRI). Usando um array de 40.000 cDNA clones, Halvorsen e cols. (49) determinaram vários genes que corretamente separam tecido maligno e adjacente de próstata, incluindo $\pi$-metilacil-CoA racemase e hepsina.

Outros autores verificaram que o perfil gênico distinguia câncer de próstata de HPB. Dhanasekeran e cols. (50), comparando 24 amostras de HPB e 36 carcinomas, identificaram alguns genes diferencialmente expressos entre eles, hepsina, PIMl, LIM, TIMP2, HEVIN. Vários autores usando diferentes plataformas identificaram uma superexpressão significativa do gene codificando a hepsina em tecidos de próstata malignos $(51,52)$, confirmada por meta-análise (53), embora a superexpressão de hepsina não tenham sido associada a resposta clínica.

No trabalho de Bull e cols. (54), conclui-se que outros 3 genes superexpressos em relação ao tecido normal podem separar câncer de hiperplasia de próstata, sendo 2 conhecidos: a cadeia $\pi 2$ da laminina e o repressor da atividade estrogênica (REA). Landers e cols. (55) sugeriram que os marcadores combinados hepsina, UDP-N-acetil- $\pi \mathrm{D}$-galactosanina transferase (GalNac-T3) e um mRNA não codificador (DD3/ PCA3) podem distinguir câncer de HPB. Ashida e cols. (56) caracterizaram a transição putativa da neoplasia intraepitelial prostática (PIN) a câncer invasivo usando microdissecção a laser para purificar as populações celulares, e sugeririam que geneticamente PIN e câncer de próstata (CaP) têm uma população de genes em comum, sustentando a hipótese de transição $\mathrm{PIN} \pi \mathrm{CaP}$.

Um aspecto importante é a classificação prognóstica de estágios iniciais da doença. No trabalho de Welsh e cols. (57), cujo objetivo foi identificar genes com uso clínico potencial, foram encontrados 20 genes diferencialmente expressos em 3 classes conforme a classificação de Gleason. Proteínas ligadoras de insulina (IGFRP 2 e 5) estavam expressas em tumores de grau mais alto. Singh e cols. (58) identificaram um conjunto de genes correlacionados com a mesma classificação, e 5 genes foram utilizados para compor um modelo capaz de predizer recorrência. Este modelo inclui: cromogranina $\mathrm{A}, \mathrm{HOXC6}$, o receptor 3 do inositol fosfato (IPTR3) e a sialiltransferase-1. Claramente, dados confirmatórios serão necessários para implementação destas determinações.

Metástase tumoral é um dos eventos mais significativos em pacientes de câncer de próstata. Amostras de metástases não são comuns e poucos trabalhos foram publicados a respeito. Alguns genes que se mostraram diferencialmente expressos em amostras primárias versus metastáticas foram IGFJP5, DANI, FAT e RAB5A (50). Outros genes foram identificados por Magee e cols. (51) e LaTulippe e cols. (59), relacionando-se ao ciclo celular, transdução do sinal, estrutura celular e regulação da transcrição, propriedades que contribuem para proliferação, interação com o meio ambiente e motilidade celular. Comparação entre células de carcinoma isoladas do tumor primário e linfonódio em modelo experimental de camundongo concluiu que os genes relacionados à metástase poderiam ser categorizados como: 1) genes codificando enzimas proteolíticas (catepsina e metaloproteases); 2 ) genes relacionados a fatores de transcrição; 3) à adesão; 4) a receptores de superfície (60).

Estudos da sinalização androgênica e progressão à andrógeno-independência têm sido dificultados porque existem poucos modelos que reproduzam adequadamente o curso clínico da doença em humanos. Utilizando a metodologia de SAGE, Xu e cols. (61) analisaram 83.000 tags derivados de linhagens celulares prostáticas na presença e ausência de andrógeno. Usando a mesma metodologia Waghray e cols. (62) analisaram 123.371 tags e ambos os grupos identificaram muitos genes em comum representando alvos diretos e indiretos da ação androgênica. Nelson e cols. (1) usaram uma plataforma customizada com 1.500 genes derivados de carcinoma de próstata e identificaram 20 genes superexpressos, alguns genes que são conhecidos por serem androgênio-responsivos (PSA, 
KLK2) e outros novos. Estudos baseados em um conjunto pequeno de linhagens celulares têm, porém, uma relevância incerta em relação à clínica.

Em um modelo experimental, Wang e cols. (63) isolaram 38 genes diferencialmente expressos em próstata ventral de ratos 48 horas após o fornecimento de androgênio a animais castrados. Seis de onze genes superexpressos eram conhecidos por serem regulados por andrógenos. Vários trabalhos revistos por Gerald (64) utilizaram o modelo do enxerto CWR22, comparando enxertos responsivos e resistentes para investigar o desenvolvimento da independência androgênica. Seis genes (FKBP5, THRA, S100P, SDCl, NCORl e APELIN) foram considerados como hiperexpressos em tumores androgênio-independentes.

Holzbeierlein e cols. (65) analisaram a expressão gênica em tumores humanos incluindo 23 amostras de câncer de próstata de pacientes não tratados; 17 amostras após 3 meses de terapia antiandrogênica e 9 casos metastáticos, sendo 3 resultantes de progressão para a hormônio-independência após 5 a 10 anos de ablação androgênica. Resistência a terapia foi associada a uma reativação da via da resposta a androgênios. Uma das características mais notáveis foi um aumento do nível do mRNA do receptores de androgênio e de genes envolvidos na síntese de precursores esteroídicos.

A maior parte dos arrays descritos foi construída com genes advindos de exons. Com o objetivo de se verificar o papel das mensagens intrônicas, transcritos foram identificados em amostras de câncer de próstata (66), e uma fração considerável de transcritos intrônicos correlacionou-se significativamente com o grau de diferenciação tumoral, aumentando a complexidade do problema.

Embora vários genes tenham sido repetidamente determinados como diferencialmente expressos durante o desenvolvimento do câncer de próstata, os resultados de muitos estudos coincidem parcialmente. Variedade de métodos, amostras, e plataformas contribuíram para esta disparidade.

Todos os trabalhos resultaram em um grande número de alvos potenciais terapêuticos para o tratamento de câncer de próstata. Uma lista contendo 89 proteínas que se correlacionaram com algum aspecto da presença ou progressão do carcinoma de próstata foi revista recentemente por Tricoli e cols. (67), e segundo os autores há 5 marcadores que apresentam um volume suficiente e convincente de dados para considerá-los como marcadores prognósticos e diagnósticos: chromogranin A (GRN-A), glutamine $S$ transferase $\pi$ l (GSTPl); o antígeno da glicosilfosfatidilinositol ancorado a membrana (PSCA), o antí- geno de membrana próstata-específico (PSMA) e um componente da telomerase que mantém as extremidades teloméricas (TERT).

Com o advento de novas tecnologias moleculares, a lista dos genes marcadores de câncer de próstata cresce dia a dia. Tentamos fornecer exemplos de marcadores potenciais. No entanto, a maior parte dos genes determinados ainda está em fase de investigação e longe do uso de uma rotina clínica, e ainda requerem validação com grande número de amostras e correlação com o processo da doença. Trazê-los do ambiente de laboratório para o uso clínico requer uma análise rigorosa e há, portanto, um longo caminho a percorrer.

\section{REFERÊNCIAS}

1. Nelson WG, De Marzo AM, Isaacs WB. Prostate cancer. NEJM 2003;349(4):366-81.

2. INCA (Instituto Nacional do Câncer). Ministério da Saúde, Brasil. Disponível em: http://www.inca.gov.br. Acessado em 15.07.2005.

3. Lee C, Kozlowski JM, Grayhack JT. Etiology of benign prostatic hyperplasia. Urol Clin Am 1995;22(2):237-46.

4. Nakano K, Fukabori Y, Itoh N, Lu W, Kan M, McKeehan $W L$, et al. Androgen-stimulated human prostate epithelial growth mediated by stromal-derived fibroblast growth factor-10 Endocr J 1999;46(3):405-13.

5. Latil A, Bieche I, Vidaud D, Lidereau R, Berthon P, Cussenot $O$, et al. Evaluation of androgen, estrogen (ER alpha and ER beta), and progesterone receptor expression in human prostate cancer by real-time quantitative reverse transcription-polymerase chain reaction assays. Cancer Res 2001;61:1919-26.

6. Geck P, Maffini MV, Szelei J, Sonnenschein C, Soto AM. Androgen-induced proliferative quiescence in prostate cancer cells: The role of AS3 as its mediator. Med Sci 2000;97(18): 10185-90.

7. Kallio PJ, Palvino JJ, Janne OA. Genetic regulation of androgen action. Prostate 1996;6:45-51.

8. Hart S. Modulation of nuclear receptor dependent transcription. Biol Res 2002;35(2):295-303.

9. Heinlein $C A$, Chang $C$. Androgen receptor (AR) coregulators: an overview. Endocr Rev 2002;23(2):175-200.

10. Chatterjee B. The role of the androgen receptor in the development of prostatic hyperplasia and prostate cancer. Mol Cell Biochem 2003;253(1/2):89-101.

11 Taplin ME, Bubley GJ, Ko YJ, Small EJ, Upton M, Rajeshkumar B, et al. Selection for androgen receptor mutations in prostate cancers treated with androgen antagonist. Cancer Res 1999;59(11):2511-5.

12. Lee DK, Chang C. Molecular communication between androgen receptor and general transcription machinery. J Steroid Biochem Mol Biol 2003;84(1):419.

Arq Bras Endocrinol Metab vol $49 n^{\circ} 5$ Outubro 2005 
13. Yeh S, Kang HY, Miyamoto H, Nishimura K, Chang HC, Ting $\mathrm{HJ}$, et al. Differential induction of androgen receptor transactivation by different androgen receptor coactivators in human prostate cancer DU145 cells. Endocrine 1999;11(2):195-202.

14. Fujimoto N, Mizokami A, Harada S, Matsumoto T. Different expression of androgen receptor coactivators in human prostate. Urology 2001;58(2):289-94.

15. Gao T, Brantley K, Bolu E, McPhaul MJ. RFG (ARA70, ELE 1) interacts with the human androgen receptor in a ligand-dependent fashion, but functions only weakly as a coactivator in cotransfection assays. Mol Endocrinol $1999 ; 13(10): 1645-56$.

16. Hsiao PW, Chang C. Isolation and characterization of ARA160 as the first androgen receptor $\mathrm{N}$-terminalassociated coactivator in human prostate cells. J Biol Chem 1999;274(32):22373-9.

17. Petre CE, Wetherill YB, Danielsen M, Knudsen KE. Cyclin $\mathrm{DI}$ : mechanism and consequence of androgen receptor co-repressor activity. J Biol Chem 2002;277(3):2207-15.

18. Shenk JL, Fisher CJ, Chen SY, Zhou XF, Tillman K, Shemshedini L. p53 represses androgen-induced transactivation of prostate-specific antigen by disrupting hAR amino- to carboxyl-terminal interaction. J Biol Chem 2001;276(42): 38472-9.

19. Wang X, Yang Y, Guo X, Sampson ER, Hsu CL, Tsai MY, et al. Suppression of androgen receptor transactivation by Pyk2 via interaction and phosphorylation of the ARA55 coregulator. J Biol Chem 2002;277(18):15426-31.

20. Muller JM, Isele U, Metzger E, Rempel A, Moser M, Pscherer A, et al. FHL2, a novel tissue-specific coactivator of the androgen receptor. Embo J 2000; 19(3):359-69.

21. Gobinet J, Auzou G, Nicolas JC, Sultan C, Jalaguier S. Characterization of the interaction between androgen receptor and a new transcriptional inhibitor, SHP. Biochemistry 2001;40(50):15369-77.

22. Giovanucci E, Stampfer MJ, Krithivas K, Brown M, Dahl $D$, Brufsky $A$, et al. The CAG repeat within the androgen receptor gene and its relationship to prostate cancer. Proc Natl Acad Sci USA 1997;94:3320-3.

23. Correa-Cerro L, Wohr $G$, Haussler J, Berthon $P$, Drelon $E$, Magin P, et al. (CAG)nCAA and $G G N$ repeats in the human androgen receptor gene are not associated with prostate cancer in a French-German population. Eur J Hum Genet 1999;7(3):357-62.

24. Stanford JL, Just JJ, Gibbs M, Wicklund KG, Neal CL, Blumenstein BA, et al. Polymorphic repeats in the androgen receptor gene: molecular markers of prostate cancer risk. Cancer Res 1997;57:1194-8.

25. Santos ML, Sarkis AS, Nishimoto IN, Nagai MA. Androgen receptor CAG repeat polymorphism in prostate cancer from a Brazilian population. Cancer Detection Prev 2003;27:321-6.

26. Nam RK, Elhaji Y, Krahn MD, Hakimi J, Ho M, Chu W, et al. Significance of CAG repeats polymorphism of the androgen receptor gene in prostate cancer progression. J Urol 2000;164:567-72.
27. Császár A, Ábel T. Receptor polymorphisms and diseases. Eur J Pharmacol 2002;414:9-22.

28. Hsing AW, Chen C, Chokkalingam AP, Gao YT, Dightman DA, Nguyen HT, et al. Polymorphic markers in the SRD5A2 gene and prostate cancer risk: a population-based case-control study. Cancer Epidemiol Biomarkers Prev 2001;10:1077-82.

29. Ntais C, Polycarpou A, loannidis JP. SRD5A2 gene polymorphisms and the risk of prostate cancer: a metaanalysis. Cancer Epidemiol Biomarkers Prev 2003; 12:618-24.

30. Soderstrom $T$, Wadelius $M$, Andersson SO, Johansson JE, Johansson S, Granath F, et al. 5 alpha-reductase 2 polymorphisms as risk factors in prostate cancer. Pharmacogenetics 2002;12:307-12.

31. Agarwal R. Cell signaling and regulators of cell cycle as molecular targets for prostate cancer prevention by dietary agents. Biochem Pharmacol 2000;60(8):1051-9.

32. Wen Y, Hu MC, Makino K, Spohn B, Bartholomeusz G, Yan DH, et al. HER-2/neu promotes androgenindependent survival and growth of prostate cancer cells through the Akt pathway. Cancer Res 2000;60(24):6841-5.

33. Lee C, Sintich SM, Mathews EP, Shah AH, Kundu SD, Perry $\mathrm{KT}$, et al. Transforming growth factor-beta in benign and malignant prostate. Prostate 1999;39(4):285-90.

34. Hayes SA, Zarnegar M, Sharma M, Yang F, Peehl DM, ten Dijke $P$, et al. SMAD3 represses androgen receptormediated transcription. Cancer Res 2001;61(5):2112-8.

35. Cericatto R, Pozzobon A, Morsch DM, Menke CH, Brum IS, Spritzer PM. Estrogen receptor-alpha, bcl2 and c-myc gene expression in fibroadenomas and adjacent normal breast: association with nodule size, hormonal and reproductive features. Steroids 2005;70(3): 153-60.

36. Reis FM, Maia AL, Ribeiro MF, Spritzer PM. Progestin modulation of $\mathrm{C}$-fos and prolactin gene expression in the human endometrium. Fertil Steril 1999;71:1 125-32.

37. Brum IS, Morsch DM, Urnauer L, Spritzer PM. Androgeninduce cell growth and c-myc expression in human non-transformed epithelial prostatic cells in primary culture. Endocrine Res 2001;27:153-69.

38. Brum IS, Morsch DM, Pozzobon A, Boeri VA, Geib G, Spritzer PM. Androgen-dependent expression of C-jun and $\mathrm{c}$-fos in human non-transformed epithelial prostatic cells (HNTEP): association with cell proliferation. Horm Res 2003;60(5):209-14.

39. Tang DG, Porter AT. Target to apoptosis: a hopeful weapon for prostate cancer. Prostate 1997;32(4):28493.

40. Fernandez A, Udagawa T, Schwesinger C, Beecken W, Achilles-Gerte E, McDonnell $T$, et al. Angiogenic potential of prostate carcinoma cells overexpressing bcl-2. J Natl Cancer Inst 2001;93(3):208-13.

41. Bonkhoff H, Fixemer T, Remberger K. Relation between $\mathrm{Bcl}-2$ cell proliferation and the androgen receptor status in prostate tissue and precursors of prostate cancer. Prostate 1998;34(4):251-8.

42. Tang DG, Li L, Chopra DP, Porter AT. Extended survivability of prostate cancer cells in the absence of trophic factors: increased proliferation, evasion of apoptosis, and the role of apoptosis proteins. Cancer 
Res 1998;58(15):3466-79.

43. Kolar Z, Murray PG, Scott K, Harrison A, Votesek B, Dusek $\mathrm{J}$. Relation of $\mathrm{BCl}-2$ expression to androgen receptor, p2 1WAF1/CIP1, and cyclin D1 status in prostate cancer. Mol Pathol 2000:53:15-8.

44. Brentani RR, Carraro DM, Verjovski-Almeida S, Reis EM, Neves EJ, de Souza SJ, et al. Gene expression arrays in cancer research: methods and applications. Crit Rev Oncol Hematol 2005;54(2):95-105.

45. Stollberg J, Urschitz J, Urban Z, Boyd CD. A quantitative evaluation of SAGE. Genome Res 2000;10(8):1241-8.

46. Yamamoto M, Wakatsuki T, Hada A, Ryo A. Use of serial analysis of gene expression (SAGE) technology. J Immunol Methods 2001;250(1/2):45-66.

47. Elek J, Park KH, Narayanan R. Microarray-based expression profiling in prostate tumors. In Vivo 2000; 14(1):173-82.

48. Ernst $T$, Hergenhahn $M$, Kenzelmann $M$, Cohen $C D$, Bonrouhi $M$, Weninger $A$, et al. Decrease and gain of gene expression are equally discriminatory markers for prostate carcinoma: a gene expression analysis on total and microdissected prostate tissue. Am J Pathol 2002;160(6):2169-80.

49. Halvorsen OJ, Oyan AM, Bo TH, Olsen S, Rostad K, Haukaas SA, et al. Gene expression profiles in prostate cancer: association with patient subgroups and tumour differentiation. Int J Oncol 2005;26(2):329-36.

50. Dhanasekaran SM, Barrette TR, Ghosh D, Shah R, Varambally $S$, Kurachi K, et al. Delineation of prognostic biomarkers in prostate cancer. Nature 2001;412(6849): $822-6$.

51. Magee JA, Araki T, Patil S, Ehrig T, True L, Humphrey PA, et al. Expression profiling reveals hepsin overexpression in prostate cancer. Cancer Res 2001;61(15):5692-6.

52. Luo J, Duggan DJ, Chen Y, Sauvageot J, Ewing CM, Bittner ML, et al. Human prostate cancer and benign prostatic hyperplasia: molecular dissection by gene expression profiling. Cancer Res 2001;61(12):4683-8.

53. Rhodes DR, Barrette TR, Rubin MA, Ghosh D, Chinnaiyan AM. Meta-analysis of microarrays: interstudy validation of gene expression profiles reveals pathway dysregulation in prostate cancer. Cancer Res 2002;62(15):442733.

54. Bull JH, Ellison G, Patel A, Muir G, Walker M, Underwood $M$, et al. Identification of potential diagnostic markers of prostate cancer and prostatic intraepithelial neoplasia using CDNA microarray. Br J Cancer 2001;84(11):15129.

55. Landers KA, Burger MJ, Tebay MA, Purdie DM, Scells B, Samaratunga $\mathrm{H}$, et al. Use of multiple biomarkers for a molecular diagnosis of prostate cancer. Int J Cancer 2005; 114(6):950-6.

56. Ashida S, Nakagawa $H$, Katagiri T, Furihata M, liizumi M, Anazawa $\mathrm{Y}$, et al. Molecular features of the transition from prostatic intraepithelial neoplasia (PIN) to prostate cancer: genome-wide gene-expression profiles of prostate cancers and PINs. Cancer Res 2004;64(17): 596372.

57. Welsh JB, Sapinoso LM, Su AI, Kern SG, Wang-Rodriguez J, Moskaluk CA, et al. Analysis of gene expression iden- tifies candidate markers and pharmacological targets in prostate cancer. Cancer Res 2001;61(16): 5974-8.

58. Singh D, Febbo PG, Ross K, Jackson DG, Manola J, Ladd $C$, et al. Gene expression correlates of clinical prostate cancer behavior. Cancer Cell 2002; 1(2):203-9.

59. LaTulippe E, Satagopan J, Smith A, Scher H, Scardino P, Reuter $V$, et al. Comprehensive gene expression analysis of prostate cancer reveals distinct transcriptional programs associated with metastatic disease. Cancer Res 2002;62(15):4499-506.

60. Chu JH, Sun ZY, Meng XL, Wu JH, He GL, Liu GM, et al. Differential metastasis-associated gene analysis of prostate carcinoma cells derived from primary tumor and spontaneous lymphatic metastasis in nude mice with orthotopic implantation of PC-3M cells. Cancer Lett 2005; (Epub ahead of print).

61. Xu LL, Su YP, Labiche R, Segawa T, Shanmugam N, McLeod DG, et al. Quantitative expression profile of androgen-regulated genes in prostate cancer cells and identification of prostate-specific genes. Int J Cancer 2001;92(3):322-8.

62. Waghray A, Schober M, Feroze F, Yao F, Virgin J, Chen $Y Q$. Identification of differentially expressed genes by serial analysis of gene expression in human prostate cancer. Cancer Res 2001;61(10):4283-6.

63. Wang Z, Tufts R, Haleem R, Cai X. Genes regulated by androgen in the rat ventral prostate. Proc Natl Acad Sci USA 1997;94(24):12999-3004.

64. Gerald WL. Gene expression analysis of prostate carcinoma. In: Ladanyi $M$, Gerald WL, editors. Expression Profiling of Human Tumors: Diagnostic and Research Applications. New Jersey:Humana Press, 2003.

65. Holzbeierlein J, Lal P, LaTulippe E, Smith A, Satagopan J, Zhang $L$, et al. Gene expression analysis of human prostate carcinoma during hormonal therapy identifies androgen-responsive genes and mechanisms of therapy resistance. Am J Pathol 2004;164(1):217-27.

66. Reis EM, Nakaya HI, Louro R, Canavez FC, Flatschart $\mathrm{AV}$, Almeida GT, et al. Antisense intronic non-coding RNA levels correlate to the degree of tumor differentiation in prostate cancer. Oncogene 2004;23(39): 6684-92.

67. Tricoli JV, Schoenfeldt M, Conley BA. Detection of prostate cancer and predicting progression: current and future diagnostic markers. Clin Cancer Res 2004; 10(12 P† 1):3943-53.

\section{Endereço para correspondência:}

Maria Mitzi Brentani

Disciplina de Oncologia (LIM24), Departamento de

Radiologia

Faculdade de Medicina da USP

Av. Dr. Arnaldo $455,4^{\circ}$ andar, sala 4112

01246-903 São Paulo, SP

Fax: (11) 3082-6580

E-mail: mbrentani@lim24.fm.usp.br 